\title{
CIVIL INTERLOCUTORY APPELLATE REVIEW IN NEW JERSEY
}

\author{
Robert L. Clifford*
}

\section{INTRODUCTION}

In New Jersey the power to promulgate rules governing the practice and procedure in the state courts is vested in the Supreme Court. ${ }^{1}$ Although the structure of these rules, particularly in the area of appellate review, is relatively straightforward, their application is not without uncertainty. The purpose of this article is to provide a coherent discussion of these rules ${ }^{2}$ and to illustrate the various avenues of appellate review.

Either of two major themes may be reflected in a body of procedural rules dealing with appellate jurisdiction:

$[O]$ ne lays its stress upon the inconvenience and expense of piecemeal reviews and the strong public interest in favor of a single and complete trial with a single and complete review - the other lays its stress upon the dangers of individual injustices which may result from the denial of any appellate review until after final judgment at the trial level. ${ }^{3}$

When New Jersey revised its rules in 1948, it chose to adopt the first-stated policy. This position, while contrary to New York's attitude, coincided with the approach of the federal system. ${ }^{4}$

Copyright (C) 1984 by Law and Contemporary Problems

* Justice, New Jersey Supreme Court. The author wishes to thank Steven A. Scolari for his assistance in preparing this article.

1. N.J. Const. art. VI, § II, para. 1; In re Mattera, 34 N.J. 259, 260, 168 A.2d 38, 40 (1968). In most civil matters the court structure is as follows: the trial level consists of the Law and Chancery Divisions of the Superior Court; the intermediate appellate level rests in the Appellate Division of the Superior Court; and the court of last resort is the supreme court.

2. This article will be limited to a consideration of the rules governing appellate review in the first instance in civil cases. In addition, it will focus solely on appeals from judicial, as opposed to administrative, actions.

3. In re Pennsylvania R.R., 20 N.J. 398, 404, 120 A.2d 94, 97 (1956).

4. Id. at 404-07, 120 A.2d at 97-98. As discussed infra notes $19 \& 27-29$ and accompanying text, New Jersey has patterned one of its exceptions to the finality rule, dealing with judgments in actions involving multiple claims or parties, after Rule 54(b) of the Federal Rules of Civil Procedure. For a discussion of FED. R. Civ. P. 54(b), see Federal Civil Appellate Jurisdiction: An Interlocutory Restatement, LAW \& CONTEMP. Probs., Spring 1984, $\S 4$ at 28-36.

In several areas, however, the rules in New Jersey express a different approach to effectuating the common attitude of the two judicial systems toward appellate review. While the federal practice has delineated specific avenues of interlocutory review by statute, see, e.g., 28 U.S.C. $\$ 1292(a)(1),(a)(2)$, (b) (1982), New Jersey has moved toward one standard for granting interlocutory appeals-appeal is granted if it is "in the interest of justice." N.J. CT. R. 2:2-4. Consequently, the courts have been left with the task of defining what types of situations fall within this strict, yet undefined, standard. See infra notes 52-66 and accompanying text. As a result, the undefined scope of interlocutory power under Rules 2:2-4 and 2:44(b) (2) may allow appeals on some orders or actions that are appealable under specific federal statutes, such as 28 U.S.C. $§ 1292(a)$, (b), and 28 U.S.C. $§ 1651$. See infra notes 95-108 and accompanying text. 
Briefly, in New Jersey the system contemplates one appeal as of right to the court of general appellate jurisdiction-the Appellate Division. ${ }^{5}$ Further appeal in most matters is allowed at the discretion of the Supreme Court. ${ }^{6}$ Under the rules of practice, appeals as of right may be taken only from final judgments, ${ }^{7}$ with three express exceptions. ${ }^{8}$

Interlocutory review is exercised only in extraordinary cases. ${ }^{9}$ The usual procedure for gaining discretionary review is by motion to the Appellate Division for leave to appeal. " There is also a "safety-valve" provision in the rules allowing the Appellate Division to grant leave to appeal, even in the absence of a formal motion, in a situation in which the appellant erroneously regards an order as final rather than interlocutory and files a notice of appeal within the allotted time for appeal." The standard for granting leave to appeal is broad enough to permit interlocutory review of certain actions and orders that are reviewable in federal practice by specific statutory authorization. ${ }^{12}$

\section{Review of Final Decisions}

The emphasis in New Jersey upon an "uninterrupted proceeding at the trial level with a single and complete review" 13 has resulted in the requirement that an appeal as of right will normally lie only from a final judgment. ${ }^{14}$ Such a judgment is one that is final as to all issues and to all parties. ${ }^{15}$ In any cause of action, the

5. See Midler v. Heinowitz, 10 N.J. 123, 129, 89 A.2d 458, 461 (1952).

6. N.J. CT. R. 2:2-1(b), 2:2-2(b). For appeals as of right to the Supreme Court, see id. 2:2-1(a).

7. Id. $2: 2-1(\mathrm{a})(1), 2: 2 \cdot 3(\mathrm{a})(1)$.

8. The first such exception deals with a custody determination in a bifurcated matrimonial action. Id. 4:79-8( $)$. The second involves an order entered pursuant to a preliminary hearing in an adoption action. Id. 4:94-5. The third relates to a trial court's certification of an interlocutory order as final in an action involving multiple claims or parties. Id. 4:42-2. The fact that orders in these three categories are final for purposes of appeal is also stated in Rule 2:2-3(a)(3). The comments to Rules 2:2-3 and 2:2-4 make clear, however, that these three exceptions to the finality rule are not exclusive. See S. PRESSLER, CURRENT NEW JeR SEY COURT Rules, Rule 2:2-3 comment (1984); id. Rule 2:2-4 comment. Further exceptions can be found in the case law dealing with the exercise of interlocutory review pursuant to Rule 2:2-4. Sel infra notes 53-69 and accompanying text.

9. N.J. CT. R. 2:2-4. See Sullivan, Interlocutory Appeals, 92 N.J.L.J. 161 (1969). Justice (then Judge) Sullivan's article has been cited by the Appellate Division as authoritative on the subject of interlocutory review under the 1969 rule changes. See Rendon v. Kassimas, 140 N.J. Super. 395, 398, 356 A.2d 416, 417 (App. Div. 1976); Butler v. Buenaga, 107 N.J. Super. 80, 83, 257 A.2d 2, 4 (App. Div. 1969), modified on other grounds sub nom. Butler v. Bonner \& Barnewall, Inc., 56 N.J. 567, 267 A.2d 527 (1970). This article will consider only interlocutory review by the Appellate Division. Interlocutory review is also available in the Supreme Court in some instances. See N.J. CT. R. 2:2-2.

10. N.J. CT. R. 2:5-6(a).

11. Id. $2: 4-4$ (b)(2). See infra notes 71.74 and accompanying text.

12. See infra notes 54-75 \& 96-109 and accompanying text.

13. Sullivan, supra note 9 , at 161 .

14. N.J. CT. R. 2:2-3. Clearly, only judgments are appealable. A judgment adjudicates some interest-personal, pecuniary, or property. Thus, there is authority for the proposition that a dismissal without prejudice is not a judgment-it adjudicates nothing. Malhame v. Borough of Demarest, 174 N.J. Super. 28, 31, 415 A.2d 358, 360 (App. Div. 1980).

15. Hudson v. Hudson, 36 N.J. 549, 553, 178 A.2d 202, 203-04 (1962); cf. Kerr v. Kerr, 239 N.J. Super. 291, 293, 323 A.2d 518, 519 (App. Div. 1974) (order appealed from was interlocutory because it resolved single issue of divorce while leaving issues of custody, alimony, and property distribution undecided); 
issues and parties will include those framed in the plaintiff's complaint as well as those raised in the defendant's answer. ${ }^{16}$ Moreover, consolidation of separate actions by the court fuses them into a single action, "requiring all issues as to all parties in all actions which have been consolidated to be disposed of before an appeal as of right may be taken by any party." 17

Although this requirement of finality seems uncomplicated, in practice it may be difficult to determine whether an order is final or interlocutory, particularly in actions involving multiple claims and multiple parties. ${ }^{18}$ This difficulty, however, is alleviated by Rule 4:42-2 of the New Jersey Court Rules, which provides a significant exception to the finality rule. Under this important rule the trial court may direct the entry of final judgment as to one or more, but fewer than all, of the claims or parties in three different situations: (1) where there is a complete adjudication of a separable claim; (2) where there is a complete adjudication of all of the rights and liabilities asserted in the litigation as to any party; or (3) where there is a partial summary judgment for payment of less than all of the claim. ${ }^{19}$ Since most questions concerning final judgment arise in the context of Rule 4:42-2, the remainder of this section will focus on its application.

Application of the certification rule is conditioned in each situation upon two factors: the trial court must expressly determine that there is no just reason for delay, and it must expressly direct the entry of judgment. ${ }^{20}$ There are two reasons for these requirements. First, unnecessary piecemeal adjudications of controversies are considered "anathema to the practice."21 Second, the Appellate Division is concerned with trial courts misusing the certification rule to control the appellate calendar through the grant of motions for leave to appeal. ${ }^{22}$ Consequently, the

Yuhas v. Mudge, 129 N.J. Super. 207, 209, 322 A.2d 824, 825 (App. Div. 1974) (order appealed from was interlocutory because it left undecided plaintiff's claims against some defendants).

16. See Delbridge v. Jann Holding Co., 164 N.J. Super. 506, 510, 397 A.2d 356, 357 (App. Div. 1978) (plaintiff's appeal of an order dismissing specific performance claim was improper because, among other claims, the defendant's action against plaintiff's son, third-party defendant, was unresolved); Girard v. Alverez, 144 N.J. Super. 259, 261-62, 365 A.2d 220, 221 (App. Div. 1976) (dismissal of plaintiff's claims without resolution of the counterclaim filed by one of the defendants was not final as to all the issues). The holdings in these cases make clear that determination of the scope of the issues and parties becomes more complex because of the allowance of joinder of claims and remedies, N.J. CT. R. 4:27-1, of parties, id. 4:28, and of multiple parties, $i d .4: 29$. In addition, the interpleader rule, id. 4:31, will affect the characterizations of the issues and parties.

17. S. PRESSLER, supra note 8, Rule 2:2-3 comment (citing Florio v. Galankis, 107 N.J. Super. 1, 4-5, 256 A.2d 497, 498 (App. Div. 1969)).

18. See supra note 16 .

19. N.J. CT. R. 4:42-2. In Haelig v. Mayor of Bound Brook Borough, 105 N.J. Super. 7, 250 A.2d 788 (App. Div. 1969), the court stated that the background and interpretations of this rule as it relates only to adjudication of a separate claim are analogous to those of Rule 54(b) of the Federal Rules of Civil Procedure. Id. at 12, 250 A.2d at 791. In 1981, the New Jersey rule was amended to coincide with the 1961 amendment to the federal rule allowing an appeal as of right upon complete adjudication of all the rights and liabilities asserted as to any party.

20. N.J. CT. R. 4:42-2.

21. Frantzen v. Howard, 132 N.J. Super. 226, 227, 333 A.2d 289, 290 (App. Div. 1975); see Sullivan, supra note 9 , at 161 .

22. See Delbridge v. Jann Holding Co., 164 N.J. Super. 506, 510, 397 A.2d 356, 357 (App.Div. 1978); S. Pressler, supra note 8 , Rule $4: 42-2$ comment. The power to grant a motion for leave to appeal is expressly reserved to the Appellate Division under Rule 2:2-4. 
trial court's certification ruling is not binding upon the appellate court. ${ }^{23}$ The scope of the Appellate Division's review extends not only to the trial court's determination that there was no just cause for delay, ${ }^{24}$ but also to its certification of an interlocutory order as final under any of the three situations stated in the rule. ${ }^{25}$

The purpose of the rule with respect to separable claims is to permit certification of a judgment that fully adjudicates a separable claim for affirmative relief even though not all the claims in the multiple claim action have been decided. ${ }^{26}$ The courts, however, have not been able to agree on a single definition of a separable claim. The issue was addressed in Haelig v. Mayor of Bound Brook Borough. ${ }^{27}$ Recognizing that the federal courts had been troubled by the same issue under Rule 54(b) of the Federal Rules of Civil Procedure, ${ }^{28}$ the court accepted the general definition that a separable claim is one that is "entirely distinct from other claims in an action and which arises from a different transaction or occurrence.",29 Unfortunately, the broad language of this standard does not develop readily identifiable factors for courts and counsel to consider. Furthermore, the "same transaction or occurrence" test was eliminated from Federal Rule 54(b) by the 1946 amendment. Moreover, the United States Supreme Court has explicitly rejected the standard. ${ }^{30}$

In practice, the courts in New Jersey have not applied a strict definition of the term "claim." Instead, they have focused on the legal right allegedly violated in each case. For example, in Haelig plaintiffs sought to enjoin the sale of property by the borough to a third party, alleging in the alternative that the contract contained an inadequate and unreasonably restrictive sale condition, that the sale was not public, and that the public sale was improperly advertised according to law. The trial court certified an order that had granted the defendant summary judgment on the issue of the allegedly restrictive sale conditions. ${ }^{31}$ The Appellate Division dismissed the appeal because certification as a final order was not warranted. The court held that plaintiffs' complaint sought the vindication of one legal right or claim-enjoining the sale. The order appealed from dealt with only one theory of recovery in support of that claim. Clearly, the claim was not completely adjudicated because the plaintiffs could still enjoin the sale based upon one of the other theories of liability. ${ }^{32}$

23. See Delbridge v. Jann Holding Co., 164 N.J. Super. 506, 510; 397 A.2d 356, 357 (App. Div. 1978).

24. Leonardis v. Bunnell, 164 N.J. Super. 338, 340, 396 A.2d 357, 359 (App. Div. 1978). In Leonardis, the court warned the appellant of its power to overturn the lower court's finding. Id.

25. See supra text accompanying note 19.

26. S. Pressler, supra note 8, Rule 4:42-2 comment; see Delbridge v. Jann Holding Co., 164 N.J. Super. 506, 510, 397 A.2d 356, 357 (App. Div. 1978).

27. 105 N.J. Super. 7, 250 A.2d 788 (App. Div. 1969).

28. Id. at $12,250 \mathrm{~A} .2 \mathrm{~d}$ at 791 .

29. 105 N.J. Super. at 12, 250 A.2d at 791 (citing Reeves v. Beardall, 316 U.S. 283 (1942), and Town of Clarksville v. United States, 298 F.2d 238, 240 (4th Cir. 1952)). The emphasis upon a different transaction is not helpful in cases in which two different legal rights or injuries may arise from the same factual situation. See, e.g., infra notes 33-35 and accompanying text.

30. Cold Metal Process Co. v. United Eng'g \& Foundry Co., 351 U.S. 445 (1956); Sears, Roebuck \& Co. v. Mackey, 351 U.S. 427 (1956).

31. 105 N.J. Super. at $9-10,250$ A.2d at 790.

32. Id. at 13, 250 A.2d at 791; see also Delbridge v. Jann Holding Co., 164 N.J. Super. 506,397 A.2d 356 (App. Div. 1978) (plaintiff sued for eviction from certain rental premises, basing each count of the 
In Heauner $v$. Uniroyal, Inc. ${ }^{33}$ plaintiffs sought monetary compensation for two different injuries-personal injuries and property damage-alleged to have resulted from use of defendant's product. Each claim was framed in a separate count and was supported by alternative theories of liability. ${ }^{34}$ At trial, the court granted defendant's motion to dismiss the personal injury count because the statute of limitations had run. Although the Appellate Division did not elaborate on the reasons for granting plaintiff's appeal, its reason was evident: dismissal in the court below barred the entire personal injury claim and all theories of recovery associated with it. Thus, the separable claim for personal injuries had been completely disposed of while the other count for property damage remained undecided. ${ }^{35}$

The second requirement is that the judgment must grant affirmative relief. This issue of whether such relief has been granted arises primarily in the context of motions for partial summary judgment in actions involving multiple claims and parties. ${ }^{36}$ On the one hand, if the trial court denies the motion, the order is interlocutory because it has not adjudicated the issue in question; ${ }^{37}$ it signifies only that the trial court believes there should be a plenary trial rather than summary disposition of the matter. ${ }^{38}$ On the other hand, if the motion is granted and is dispositive of a separable claim, the court may direct immediate entry of the judgment as final under the certification rule. ${ }^{39}$

The second situation in which an order may be certified as final involves those judgments that completely adjudicate all the rights and liabilities asserted as to any party in a multiple party action. ${ }^{40}$ This part of the New Jersey rule is similar

complaint upon an alternative theory of recovery and seeking equitable and monetary relief under each theory. The trial judge dismissed the prayers for equitable relief and, pursuant to Rule 4:42-2, certified the order as final. The appellate court, however, dismissed the appeal because the plaintiffs complaint sought to vindicate only one legal right-the eviction from the premises. The order appealed from dealt with only one form of compensation for that alleged wrong-equitable relief. It did not, however, decide the issue of compensation in monetary terms under either theory of liability).

33. 63 N.J. 130, 305 A.2d 412 (1973).

34. Id. at 133,305 A.2d at $413-14$.

35. Id. at 133 n.2, 305 A.2d at 414 n.2; see also S. PRESSLER, supra note 8, Rule 4:42-2 comment (discussing Heavner and suggesting that the focus of defining a claim is on the injury for which compensation is sought).

36. See S. PRESSLER, supra note 8, Rule 4:42-2 comment; see also Rendon v. Kassimas, 140 N.J. Super. 395, 398, 356 A.2d 416, 417 (App. Div. 1976). The motion may be dispositive as to more than one separable claim but fewer than all the claims or as to all the rights and liabilities against any party. See infra note 42 and accompanying text (discussing the 1981 amendment to Rule 4:42-2).

37. See A \& P Sheet Metal Co. v. Hansen, Inc., 140 N.J. Super. 566, 573, 357 A.2d 37, 40 (Law Div. 1976). Other types of orders that do not affirmatively adjudicate any issue may involve decisions concerning the joinder of claims and parties. See supra note 16.

38. See Rendon v. Kassimas, 140 N.J. Super. 395, 398, 356 A.2d 416, 417 (App. Div. 1976). The comment to Rule $4: 42-2$ states that the trial court lacks the power to certify in these situations. $S$. PRESSLer, supra note 8, Rule 4:42-2 comment. The reason for the concern over improper certification of such an order is particularly evident in situations in which one of several defendants suffers denial of his motion for summary judgment as to all claims against that defendant. Allowing immediate appeal by that defendant is an abuse of the certification rule because until an order is affirmatively entered declaring him free of liability, the trial court has not adjudicated the issue of that defendant's liability. See A \& P Sheet Metal Co. v. Hansen, 140 N.J. Super. 566, 575, 356 A.2d 37, 40 (Law Div. 1976).

39. See Rendon v. Kassimas, 140 N.J. Super. 395, 398, 356 A.2d 416, 417 (App. Div. 1976).

40. S. PRESSLER, supra note 8 , Rule 4:42-2 comment. 
to Federal Rule 54(b) and has been in existence only since $1981 ;{ }^{41}$ as a result, to date no cases in New Jersey have applied the provision. Nevertheless, in light of the similarity between this component of Rule 4:42-2 and Federal Rule 54(b), ${ }^{42}$ reference to the development of the federal law in this area would be informative. ${ }^{43}$ The federal courts have had little difficulty determining whether an order completely decides the rights and liabilities of a single party.

The last part of the certification rule, which allows the trial court to certify as final a partial summary judgment granting payment of less than all of the damages claimed, does not have a counterpart in the federal rules ${ }^{44}$ There is an implicit requirement that the trial court certify only an order that affirmatively grants the motion, ${ }^{45}$ as in the case of motions for partial summary judgment with respect to more than one but fewer than all claims and parties. However, certification of an order as final in those cases renders only the judgment and the issues decided therein appealable. When a partial summary judgment awarding money damages is made final, not only is it appealable but also execution can immediately be issued on the judgment. ${ }^{46}$

As the previous discussion illustrates, the certification rule applies only to orders issued before or during trial that adjudicate certain defined units of litigation but that are not final as to all issues and parties. It has no application to other judgments such as pendente lite orders for support, counsel fees, or orders restoring cases to the trial calendar. These adjudications are not final and thus may be appealed only by motion for leave to appeal to the Appellate Division. ${ }^{47}$ Moreover, the certification rule has no application to orders issued after the entry of judgment, such as orders seeking to vacate or reopen a judgment. One commen-

41. In discussing the similarity between Rule 4:42-2 and FED. R. CIV. P. 54(b), as amended in 1961, one Appellate Division panel, in Haelig v. Mayor of Bound Brook Borough, 105 N.J. Super. 7, 250 A.2d 788 (App. Div. 1969), suggested in a footnote that as far back as 1955 , New Jersey recognized the application of the certification rule to orders adjudicating claims as to any party in actions involving multiple claims and parties. Id. at 12, 250 A.2d at 791 (citing Mortgage Corp. v. Aetna Casualty and Sur. Co., 19 N.J. 24, 28, 115 A.2d 58, 61 (1955)). Prior to the 1981 amendment to Rule 4:42-2, however, several other cases decided by appellate division panels expressly refused to recognize the application of the certification rule to this situation. See Sanner v. Ford Motor Co., 154 N.J. Super. 407, 408, 381 A.2d 805, 805 (App. Div. 1977); Zweifel v. Morgan, 145 N.J. Super. 35, 37-38, 366 A.2d 1003, 1004 (App. Div. 1976); Yuhas v. Mudge, 129 N.J. Super. 207, 209, 322 A.2d 824, 825 (App. Div. 1974); see also Sullivan, supra note 9, at 165.

42. See Haelig v. Mayor of Bound Brook Borough, 105 N.J. Super. 7, 12, 250 A.2d 788, 791 (App. Div. 1969).

43. See 6 J. Moore, W. Taggart, \& J. Wicker, Moore's Federal Practice 154.34 [2.-2] (2d ed. 1982). It may also be helpful to examine several pre-1981 amendment cases in which the Appellate Division granted leave to appeal from orders that adjudicated all of the rights and liabilities of a single party in a multiple-party action. See Sanner v. Ford Motor Co., 154 N.J. Super. 407, 408, 381 A.2d 805, 805 (App. Div. 1977); Zweifel v. Morgan, 145 N.J. Super. 35, 37-38, 366 A.2d 1003, 1004 (App. Div. 1976); Sobin v. M. Frisch \& Sons, 108 N.J. Super. 99, 101, 260 A.2d 227, 229 (App. Div. 1969).

44. See S. Pressler, supra note 8, Rule 4:42-4 comment; id. Rule 4:46-2 comment. The adoption of these provisions overruled the contrary holding of Paolucci v. 358 Market Street, Inc., 66 N.J. Super. 411 , 169 A.2d 221 (Law Div. 1961).

45. See supra notes $36-39$ and accompanying text.

46. S. PRESSLER, supra note 8 , Rule 4:46-3 comment.

47. Sullivan, supra note 9 , at 161 . However, a pretrial order quashing a writ of attachment is a final judgment from which an appeal can be taken as of right, Landy v. Lesavoy, 20 N.J. 170, 175, 119 A.2d 11 , 13 (1956), for the reason that unless the order is immediately appealable, the subject matter of the suit may be purposely removed from the jurisdiction by the defendant, rendering the suit meaningless. 
tator has stated that the decisions in this area classifying the various orders as final or interlocutory are not harmonious. ${ }^{48} \mathrm{He}$ has suggested that generally a postjudgment order "denying relief is final and should be the subject of a right of review, whereas an order granting relief, such as reopening a judgment is not final because the litigation goes on, and would be appealable only if leave is granted."49

\section{III}

\section{INTERLOCUTORY REVIEW}

\section{A. The New Jersey Standard: "In the Interest of Justice"}

If an order cannot be appealed as of right from a final judgment or from one of the exceptions to the finality rule, ${ }^{50}$ then it is interlocutory and an appeal must be sought by application to the Appellate Division under Rule 2:5-6(a) of the New Jersey Court Rules. ${ }^{51}$ The Appellate Division may grant leave to appeal when it believes that such an exercise of its discretionary power is "in the interest of justice." 52 This standard for grant of leave to appeal, adopted in the 1969 revision of the court rules, is a change from the former standard of "substantial grounds of appeal." 53 While the comment to Rule 2:5-6(a) is silent on whether there is any significance to this change in wording, one noted commentator has suggested that the standard is the same; it is a strict standard and should allow the discretion to grant leave to appeal from an interlocutory order to be exercised only sparingly. ${ }^{54}$ Leave is "granted only in the exceptional case where, on a balance of interests,

48. Sullivan, supra note 9 , at 165

49. Id. (citing In re Old Colony Coal Co., 49 N.J. Super. 117, 123, 139 A.2d 302, 306 (App. Div. 1958)).

50. See supro notes 8-9 and accompanying text.

51. This rule requires that application be made within fifteen days after the entry of the order being appealed. See also N.J. CT. R. 2:4-4(b)(2); infra notes 67.70 and accompanying text.

52. N.J. CT. R. 2:2-4. Grant of leave to appeal under this rule does not automatically stay the proceedings in the trial court or the order that is the subject of the motion. Id. 2:5-6(a), (c), 2:9-5(a). A stay of either or both can be granted by the trial court on its own motion, id. 2:5-6, or on the motion of one of the parties, id. 2:9-5. The importance of a stay in the proceedings is evident in situations in which the trial court has excluded evidence that is vital to the plaintiff's case. In order to avoid the foreseeable entry of an adverse judgment, the plaintiff should move to stay the proceeding while he applies for discretionary review of his interlocutory order. See infra notes 61-62 \& 108-09 and accompanying text. In addition, the significance of a stay of the order being appealed is apparent in multiple-party actions in which the trial court has entered a partial summary judgment in favor of one of several defendants that adjudicates all the rights and liabilities against this one defendant, including his counterclaim for damages against the plainiff. On appeal, the plaintiff should move to stay the enforcement of partial summary judgment in order to avoid paying the damages for which his liability has been determined under the defendant's counterclaim.

53. Sullivan, supra note 9, at 161 (citing In re Pennsylvania R.R., 20 N.J. 398, 120 A.2d 94 (1956)). The emphasis upon the extraordinary nature of review reflects the strong public policy against piecemeal review. See supra notes 4,21 and accompanying text.

As discussed infra notes $70-71$ and accompanying text, the standard for grant of leave to appeal upon motion of a party, N.J. CT. R. 2:2-4, and on the appellate court's own motion, id. 2:4-4(b)(2), is the same. Some appellate courts, however, have granted leave under Rule 2:4-4(b)(2) without due consideration to the strict nature of this standard. This sometimes occurs in actions involving multiple claims and parties, with orders that adjudicate one or more but fewer than all of the claims or all the rights and liabilities as to any party. See infra notes $76-88$ and accompanying text.

54. Sullivan, supra note 9 , at 161 . 
justice suggests the need for review of the interlocutory order in advance of final judgment."55

Unfortunately, the broad language of that standard has not aided the courts in the formulation of specific factors that can be understood and applied by counsel. Occasionally the courts have exercised their powers of interlocutory review without explaining their reasons for granting this extraordinary relief. Therefore, to understand when interlocutory review may, "in the interest of justice," be granted requires one to examine closely the situations in which the courts have exercised their discretionary power previously.

The Appellate Division has granted review of orders that raise questions central to the plaintiff's ability to maintain a viable cause of action, employing this power most often with respect to pretrial orders. In Jacobs $v$. Pendel, 56 the court granted leave to appeal from a trial court order denying counsel's motion for leave to withdraw during the pendency of the action. ${ }^{57}$ In Franklin $v$. Milner, ${ }^{58}$ a trial court order in a medical malpractice case compelling discovery of two letters written by plaintiff's prospective expert witness was reviewed by the Appellate Division under its discretionary authority. ${ }^{59}$ In Vasily $v$. Cole, ${ }^{60}$ leave to appeal was granted from an order granting defendant's motion to restrict the material considered by a medical malpractice panel to that which was submitted to it at a pretrial hearing. ${ }^{61}$ Finally, in Lusky v. Capasso Bros., ${ }^{62}$ leave to appeal was granted, on the court's own motion, from an interlocutory order denying a motion to maintain a class action. ${ }^{63}$

The Appellate Division has granted interlocutory review from similar orders entered during the course of the trial. In Hamilton v. Letellier Construction Co. ${ }^{64}$ the court granted plaintiff's motion for leave after the trial court had excluded the testimony of plaintiff's expert witnesses. The testimony was excluded because plaintiff had not given defendant the witnesses' names. The Appellate Division reversed the trial court, ruling that the exclusion of the evidence was tantamount to a dismissal of the action. ${ }^{65}$

The Appellate Division has also exercised its discretionary powers to review novel issues. In Eisen $v$. Kostakos, ${ }^{66}$ the court granted review of an order declaring a default on a real estate mortgage. The court granted the appeal because it raised "an important question in the mortgage field that ha[d] not specifically been dealt with in New Jersey by an appellate court." 67 Similarly, in Vasily $v$. Cole, ${ }^{68}$ the

55. Id.

56. 98 N.J. Super. 252, 236 A.2d 888 (App. Div. 1967).

57. Id. at 254, 236 A.2d at 889; see also Kreigsman v. Kreigsman, 150 N.J. Super. 474, 478-79, 375 A.2d 1253, 1255 (App. Div. 1977) (court granted interlocutory review of a similar order on its own motion pursuant to Rule 2:4-4(b)(2)).

58. 150 N.J. Super. 456, 375 A.2d 1244 (App. Div. 1977)

59. Id. at $458,375 \mathrm{~A} .2 \mathrm{~d}$ at 1245 .

60. 173 N.J. Super. 152, 413 A.2d 954 (App. Div. 1980).

61. Id. at $157,413 \mathrm{~A} .2 \mathrm{~d}$ at 957 .

62. 118 N.J. Super. 369, 287 A.2d 736 (App. Div. 1972).

63. Id. at 371,287 A.2d at 737.

64. 156 N.J. Super. 336, 383 A.2d 1168 (App. Div. 1978)

65. Id. at $338,383 \mathrm{~A} .2 \mathrm{~d}$ at 1169 .

66. 116 N.J. Super. 358, 282 A.2d 421 (App. Div. 1971).

67. Id. at $366,282 \mathrm{~A} .2 \mathrm{~d}$ at 424 . 
Appellate Division granted leave to appeal from an order restricting material to be considered by a medical malpractice panel because "[ $\mathrm{t}$ ] had] not been considered in any previously reported decision in this state." 69

\section{B. Extension of Time for Appeal}

When considering whether review will be permitted under the "in the interest of justice" standard, counsel must also ask whether an order is in fact interlocutory. Unfortunately, counsel sometimes have the mistaken notion that an interlocutory order is final ${ }^{70}$ and consequently follow the procedures for filing an appeal from a final judgment. Instead of filing an application for leave to appeal within fifteen days of the entry of the interlocutory order as required, ${ }^{71}$ counsel files a notice of appeal from a final judgment within the corresponding forty-five day period. ${ }^{72}$ Because of this frequent mistake, Rule 2:4-4(b)(2) of the New Jersey Court Rules allows the Appellate Division to treat the notice of appeal as an application for leave to appeal and to grant leave nunc pro tunc, provided that the notice of appeal was filed within the forty-five day time requirement of Rule 2:4-1 for appeals from final judgments.

The standard used to grant leave to appeal nunc pro tunc is the same as the standard applied under Rule 2:2-4 of the New Jersey Court Rules. ${ }^{73}$ The grant of such an appeal is extraordinary relief that should be exercised only when required by the interests of justice. ${ }^{74}$ The opportunity to exercise this power often arises in multiple claims and parties actions. However, the decisions of the appellate courts are not consistent with respect to these interlocutory orders.

One line of Appellate Division cases exhibits a strikingly permissive attitude

68. 173 N.J. Super. 152, 413 A.2d 954 (App. Div. 1980).

69. Id. at 157,413 A. $2 \mathrm{~d}$ at 957 .

70. Sullivan, supra note 9 , at 165 . The mistake often arises under N.J. CT. R. 2:2-3(a), which authorizes appeals as of right from final judgments arising out of the use of the certification rule, N.J. CrT. R. $4: 42-2$, in actions involving multiple claims and parties. Typically, an interlocutory order is either erroneously certified as final by the trial court, e.g., Delbridge v. Jann Holding Co., 164 N.J. Super. 506, 397 A.2d 356 (App. Div. 1978), or is believed by counsel to be final, e.g., Ibberson v. Clark, 182 N.J.Super. 300,440 A.2d 1157 (App. Div. 1982).

71. N.J. CT. R. 2:5-6(a).

72. Id. 2:4-1. Because of the nature of the filing process, these mistakes are not discovered by the Appellate Division until the briefs and appendices are sent out to the court and the matter is listed for oral argument. See Sullivan, supra note 9, at 165 . Although the respondent has the responsibility and the right to file a timely motion to dismiss these improper appeals, this right is, unfortunately, almost never exercised. Id.; see also Brown v. Brown, 147 N.J. Super. 156, 157, 370 A.2d 895, 896 (App. Div. 1977); Butler v. Buenaga, 107 N.J. Super. 80, 82-83, 257 A.2d 2, 4 (App. Div. 1969), modified on other grounds sub nom. Butler v. Bonner \& Barnewall, Inc., 56 N.J. 567, 267 A.2d 527 (1970). Consequently, the appellate courts often grant leave to appeal nunc pro tunc solely because both sides have briefed the issues. For further discussion of the consequences of these actions and of the efforts to alleviate this problem, see infra notes $77,83-88$ and accompanying text.

73. See Kreigsman v. Kreigsman, 150 N.J. Super. 474, 375 A.2d 1253 (App. Div. 1977), and Jacobs v. Pendel, 98 N.J. Super. 252, 236 A.2d 888 (App. Div. 1967), in which the Appellate Division granted interlocutory review of orders declining to relieve counsel during the pendency of the action. In Kreigsman the court granted leave on its own motion pursuant to Rule 2:4-4(b)(2). 150 N.J. Super. at 478-79, 375 A.2d at 1255. In Jacobs the court granted leave on appellant's motion under Rule 2:2-4. 98 N.J. Super. at 254,236 A.2d at 889 .

74. See Delbridge v. Jann Holding Co., 164 N.J. Super. 506, 509-10, 397 A.2d 356, 357-58 (App. Div. 1978); Frantzen v. Howard, 132 N.J. Super. 226, 227, 333 A.2d 289, 290 (App. Div. 1975). 
toward granting the extraordinary remedy of leave to appeal nunc pro tunc. ${ }^{75}$ While these courts recognize that the appeals were filed erroneously, they do not offer substantial reasons for granting leave. Instead, because the filing process has allowed the erroneous appeals to proceed past the presentation of briefs, these courts feel compelled to decide the merits of the appeals; consequently, not only is there a disruption of the judicial process at the trial level and a resulting piecemeal review of cases, but there is also an unwarranted transfer of control of the appellate calendar to the trial courts. ${ }^{76}$

A second line of Appellate Division decisions reveals a commitment to upholding the integrity of the interlocutory review process. ${ }^{77}$ In Rendon $v$. Kassimas, $^{78}$ the trial court incorrectly certified as final an order that denied a motion for partial summary judgment with respect to plaintiff's claim for pain and suffering against one of the defendants. The appellate court's reasons for expressly refusing to exercise its interlocutory power under Rule 2:4-4(b)(2) were threefold: (1) the order appealed from did not adjudicate any issue-it signified only that there should be a plenary disposition of the pain and suffering claim; (2) the motion for summary judgment was premature because it dealt only with a subsidiary damage issue and left open the question concerning the defendant's liability as to other damage issues; and (3) the parties on appeal raised an issue that was never presented in the trial court. ${ }^{79}$ In Rybeck $v$. Rybeck, ${ }^{80}$ the court heard a constitutional challenge to the state's No-Fault Act. The plaintiffs incorrectly appealed as of right an order denying their motion for summary judgment. Although the court recognized that the constitutional issues raised in the case involved legal issues of public importance that could trigger the exercise of its power under Rule 2:4-4(b) (2), it decided not to act. Since the parties had settled after the filing of the appeal, the court felt that "the case in its present posture [was] not the proper vehicle for a determination . . . [of a] broad-based attack against the constitutionality of the statute." 81

Occasionally, the Appellate Division has warned both parties that the permissive practice of granting leave to appeal nunc pro tunc will no longer continue. In

75. See, e.g., Ibberson v. Clark, 182 N.J. Super. 300, 303, 440 A.2d 1157, 1158 (App. Div. 1982); Leonardis v. Bunnell, 164 N.J. Super. 338, 340, 396 A.2d 357, 359 (App. Div. 1978); Girard v. Alverez, 144 N.J. Super. 259, 262, 365 A.2d 220, 221 (App. Div. 1976); Kerr v. Kerr, 129 N. J. Super. 291, 293, 323 A.2d 518, 519 (App. Div. 1974); Yuhas v. Mudge, 129 N.J. Super. 207, 209, 322 A.2d 824, 825 (App. Div. 1974).

76. See supra notes 21-22 and accompanying text.

77. See, e.g., Delbridge v. Jann Holding Co., 164 N.J. Super. 506, 509-10, 397 A.2d 356, 357 (App. Div. 1978); Rybeck v. Rybeck, 150 N.J. Super. 151, 155, 375 A.2d 269, 271 (App. Div. 1977); Brown v. Brown, 147 N.J. Super. 156, 157, 370 A.2d 895, 896 (App. Div. 1977); Rendon v. Kassimas, 140 N.J. Super. 395 , 398-99, 356 A.2d 416, 417 (App. Div. 1976); Frantzen v. Howard, 132 N.J. Super. 225, 227, 333 A.2d 289, 289-90 (App. Div. 1975).

78. 140 N.J. Super. 395, 356 A.2d 416 (App. Div. 1976).

79. Id. at $398-99,356 \mathrm{~A} .2 \mathrm{~d}$ at 417 .

80. 150 N.J. Super. 151, 375 A.2d 269 (App. Div. 1977).

81. Id. at $155-56,375 \mathrm{~A} .2 \mathrm{~d}$ at 271 . In other cases the courts have not articulated any substantial reason for refusing to grant the appeal nunc pro tunc. See, e.g., Delbridge v. Jann Holding Co., 164 N.J. Super. 506, 509-10, 397 A.2d 356, 357 (App. Div. 1978); Frantzen v. Howard, 132 N.J. Super. 226, 227, 333 A. $2 d$ at 289, 289-90 (App. Div. 1975). 
Butler v. Buenaga, ${ }^{82}$ the court decided to grant review of an interlocutory order that was incorrectly certified as final. The court continued:

In doing so we emphasize for the benefit of the Bar that in the future we may not follow such a course. Moreover, it should be noted that, in a situation when an appeal has been improvidently filed, respondent has a responsibility to the court to file a timely motion to dismiss the appeal. ${ }^{83}$

Eight years later, in Brown v. Brown, ${ }^{84}$ the Appellate Division put teeth in this warning by expressly refusing to grant leave to appeal from an interlocutory order that was incorrectly filed and lacked good cause for review. ${ }^{85}$

Whether this policy of strict application of the rules governing interlocutory review will continue in the future is uncertain. As the earlier discussion illustrates, the courts are not unified in their approach to this problem. However, in light of the Brown opinion and the other cases that have strictly applied the standard of review under Rule 2:4-4(b)(2), ${ }^{86}$ counsel for the appellant might be wise to file both a notice of appeal and a motion for leave to appeal in those situations in which he is uncertain as to the nature of his appeal. ${ }^{87}$ By so doing, he may avoid dismissal of the appeal and thus help his own cause by enabling the court to decide the merits.

Even if the appellant has filed his interlocutory appeal under the proper procedures, there is no guarantee that he will receive a plenary disposition. In 1978 , the court rules were amended to allow a summary disposition practice in the Appellate Division. ${ }^{88}$ The purpose of the change was "to provide a pretranscript, pre-argument opportunity for the screening out of appeals whose ultimate outcome is so clear as not to require for decision full perfection and hearing." 89 Although any party to the appeal, as well as the Appellate Division itself, may make this motion, it has rarely been employed since its inception. ${ }^{90}$

\section{Comparison Between New Jersey and Federal Rules}

As previously discussed, ${ }^{91}$ New Jersey's inhospitable attitude toward most interlocutory appeals is similar to that of the federal courts. However, the means

82. 107 N.J. Super. 80, 257 A.2d 2 (App. Div. 1969), modified on other grounds sub nom. Butler v. Bonner \& Barnewall, Inc., 56 N.J. 567, 267 A.2d 527 (1970).

83. Id. at 83,257 A.2d at 4 .

84. 147 N.J. Super. 156, 370 A.2d 895 (App. Div. 1977)

85. Id. at $157,370 \mathrm{~A} .2 \mathrm{~d}$ at 896 . In order for the appellate courts to perform this judicial function faithfully, it is clear that they will have to follow the strict, albeit correct, view of the Broun case. In addition, the assistance of members of the Bar on both sides of an appeal would greatly assist in alleviating this misuse of the appellate process.

86. See supra note 77.

87. See Appellate Division Practice Checklist, 104 N.J.L.J. 489 (1979). This procedure is followed in Supreme Court practice. See Deerfield Estates, Inc. v. Township of East Brunswick, 60 N.J. 115, 286 A.2d 498 (1972).

88. N.J. CT. R. 2:8-3(b). Disposition under this rule is distinct from dismissal under Rule 2:8-2, which is based upon technical and jurisdictional grounds such as mootness, absence of an indispensable party, or lack of jurisdiction. See S. Pressler, supra note 8, Rule 2:8-2 comment.

89. S. PrESSLER, supra note 8, Rule 2:8-3(b) comment.

90. A recent search found only five cases in which the motion for summary disposition had been employed. In four out of the five cases the appellant had made the motion; in the fifth case the court had acted on its own motion.

91. See supra notes $3-4$ and accompanying text. 
chosen by the two judicial systems to effectuate this goal have diverged over time. In 1948, the New Jersey practice rule pertaining to appellate review permitted appeals only from final judgments, except in four separate classes, two of which paralleled the federal precedent later expressed in 28 U.S.C. $\S 1292(a)(1)$ and (2). Those two classes concerned review of interlocutory orders relating to injunctions and receiverships. The other two New Jersey exceptions dealt with challenges to jurisdiction or the propriety of temporary restraining orders. ${ }^{92}$ Today, these specific exceptions to the finality rule no longer exist in the New Jersey Court Rules. The only specified exceptions are set forth in Rule $2: 2-3(\mathrm{a})(3) ;{ }^{93}$ the major exception relates to certification of orders adjudicating more than one but fewer than all of the claims in a multiple claim and multiple party action. All other exceptions to the finality requirement must meet the "in the interest of justice" standard for a grant of leave to appeal as allowed under Rules 2:2-4 and 2:4-4(b) (2). ${ }^{94}$

Under the auspices of that broad standard, some of the specific avenues of appellate review expressly provided in the federal statutes may also be available in New Jersey by way of interlocutory review. For instance, suppose a plaintiff brings an action to enjoin the defendant because the defendant's activity is causing irreparable harm to the plaintiff. He may attempt to secure a temporary injunction before trial pursuant to Rule 4:52-1 of the New Jersey Rules Governing Civil Practice if he feels he is in danger of immediate and irreparable damage. If the motion for the temporary injunction is denied, since there is no parallel to 28 U.S.C. $\S 1292(\mathrm{a})(1)^{95}$ in the New Jersey rules, plaintiff's only recourse is to an application for leave to appeal to the Appellate Division ${ }^{96}$ and to move to stay the permanent injunction proceedings. ${ }^{97}$

Although no cases decided under the current rules have been found in which interlocutory review was granted for denial of a temporary restraining order, ${ }^{98}$ the Appellate Division's use of its discretionary power in the area of pretrial orders suggests the likelihood of such a result. ${ }^{99}$ The analysis in the decisions involving pretrial orders suggests that an appellate court is willing to grant an interlocutory appeal in cases in which the order appealed from may severely damage the appellant's cause of action. For example, in Franklin $v$. Milner, ${ }^{100}$ the court reviewed a lower court order compelling the discovery of certain evidence. Arguably, the evidence was of such importance to plaintiff's cause of action that the Appellate

92. See In re Pennsylvania R.R. Co., 20 N.J. 398, 406-07, 120 A.2d 94, 98 (1956).

93. Rule 2:2-3(a)(3) summarizes exceptions to the finality requirement that are contained elsewhere in the New Jersey Court Rules. See supra note 8.

94. See supra notes $52 \& 71$ and accompanying text. Consequently, this review is capable of encompassing any appealable order, as required in the interest of justice.

95. This statute allows the federal appellate courts to review interlocutory orders "granting, continuing, modifying, refusing or dissolving injunctions, or refusing to dissolve or modify injunctions . . . " 28 U.S.C. $\S 1291$ (a) (1982).

96. N.J. CT. R. 2:2-4, 2:5-6(a).

97. Id. $2: 9-5(\mathrm{~b})$.

98. See Galler v. Slurzberg, 22 N.J. Super. 477, 482, 92 A.2d 89, 91 (App. Div. 1952) (holding that interlocutory orders granting injunctions are appealable). It should be noted that this case was decided under one of the earlier forms of the New Jersey practice rules.

99. See supra notes $56-63$ and accompanying text.

100. 150 N.J. Super. 456, 375 A.2d 269 (App. Div. 1971); see supra notes 58-59 and accompanying text. 
Division believed it would be in the interest of justice to review the discovery order; otherwise, the case might have wastefully proceeded to a foreseeable dismissal because of insufficient evidence. Similarly, it may also be argued that failure to review the order denying plaintiff's motion for a temporary injunction would result in a meaningless trial. If plaintiff were to win on the merits, the judgment would in no way compensate the plaintiff for the irreparable injury that might have occurred because of defendant's continued activity. ${ }^{101}$

Another example of how New Jersey's single standard of interlocutory review may serve as an equivalent to a specific avenue of appeal under federal law is provided by 28 U.S.C. $\S 1292(\mathrm{~b})$. This statute expressly allows the federal district court to certify for appeal an interlocutory order when the court is of the opinion that the order involves "a controlling question of law as to which there is substantial ground for difference of opinion and that an immediate appeal from this order may materially advance the ultimate termination of the litigation . . . ."102 In Eisen v. Kostakos ${ }^{103}$ interlocutory review under Rule 2:4-4(b)(2) may have constituted the judicially created equivalent to $\S 1292(\mathrm{~b})$. The court granted review of a trial court order declaring a default on a real estate mortgage because the appeal raised an important question in the mortgage field that had not previously been dealt with by an appellate court. ${ }^{104}$

The issuance of a writ of mandamus, authorized under 28 U.S.C. $\$ 1651,{ }^{105}$ may provide still another illustration of how a similar avenue of appeal is available in New Jersey under the single standard of interlocutory review provided by Rules 2:2-4 and 2:4-4(b)(2). It is well settled in the federal practice that the writ is to be used as a means of appellate review "only in the exceptional case where there is a clear abuse of discretion or 'usurpation of judicial power' [by the trial court] . . . ."106

An analogous rule was applied in Hamilton v. Letellier Construction Co., ${ }^{107}$ in which the court granted leave to appeal based on the trial court's abuse of discre-

101. See Appellate Division Practice Checklist, supra note 87, at 490 (discussing procedure for seeking emergency relief).

102. 28 U.S.C. $\S 1292(b)(1982)$.

103. 116 N.J. Super. 358, 282 A.2d 421 (App. Div. 1971).

104. Id. at 366,282 A.2d at 424 .

105. The statute states: "The Supreme Court and all courts established by Act of Congress may issue all writs necessary or appropriate in aid of their respective jurisdictions and agreeable to the usages and principles of law." 28 U.S.C. $\$ 1651$ (a) (1976).

106. Bankers Life \& Casualty Co. v. Holland, 346 U.S. 379, 383 (1953); see also Schlagenhauf v. Holder, 379 U.S. 104, 111 (1964); Ex parle Fahey, 332 U.S. 258, 259-60 (1946). It is also established that writs of mandamus cannot be used as a substitute for appeals prior to final judgment, Bankers Life \& Casualty Co. v. Holland, 346 U.S. at 383 (citing Ex parle Fahey, 332 U.S. at 260), nor can they be used in cases where review can be had under other means, Bankers Life, 346 U.S. at 383 (citing Ex parte Rowland, 104 U.S. 604,617 (1882)). The reason for this restriction is that the writ is "a supplemental review power conferred on the courts by Congress [in addition to those powers granted under $\S 1292$ ]". Bankers Life, 346 U.S. at 383. These restrictions in no way affect the statutory equivalency argument, however, because in New Jersey all the power of the appellate court to grant interlocutory review is derived from the single standard of "in the interest of justice" provided by Rule 2:2-4.

For examples of cases decided under 28 U.S.C. $\$ 1651$ on the ground of "clear abuse of discretion," see Pacific Union Conference of Seventh-Day Adventists v. Marshall, 434 U.S. 1305, 1307-08 (1977); Bankers Life \& Casualty Co. v. Holland, 346 U.S. 379, 382-84 (1953).

107. 156 N.J. Super. 336, 383 A.2d 1168 (App. Div. 1978). 
tion. Plaintiff sought to introduce evidence by two expert witnesses whose names had not been given to defendant in response to an earlier interrogatory. He also failed to amend the answer to the interrogatory within the required time period. Consequently, the trial court excluded the witnesses' testimony and struck their reports from the record, even though the court had the discretion in extraordinary cases to extend the amendment period in order to prevent a manifest injustice. The Appellate Division granted leave to appeal and vacated the order. According to the court, it was clear that plaintiff needed the expert witnesses to establish his cause of action; therefore, the exclusion of this evidence was tantamount to a dismissal of the action - a result that could have been avoided had the trial court not exercised its discretion erroneously. ${ }^{108}$

\section{IV}

\section{Conclusion}

Knowing a judicial system's underlying attitude toward the purpose of appellate review is only the first step-albeit an important one-in the process of understanding the various avenues of review. One must also be aware of the methods developed to ensure that the system functions properly. Differences in approach can be striking, as evidenced by a comparison of the methods chosen in New Jersey and in the federal practice.

New Jersey and the Federal Rules begin with the same basic premisepeicemeal appellate review should be avoided. Both systems permit interlocutory appeals only under exceptional circumstances; however, their respective methods of determining when review is available are radically different. New Jersey's single standard-whether review is "in the interest of justice"-attempts to achieve fairness in individual cases and places tremendous discretion in the Appellate Division judges. The emphasis of New Jersey Rule 2:2-4 on judicial discretion indicates a confidence that the court will examine each factual situation and decide in the best interests of the individual litigants. The single standard works well in New Jersey, and the loss of predictability is a tolerable price to pay for the flexibility and fundamental fairness that the system provides.

In contrast, the federal approach, at least in concept, places more faith in the principle that justice requires equal treatment of all those similarly situated. Consistent rules should govern each situation so that all persons have identical rights under the law. Perhaps there is a fear that discretion begets privilege and inequality.

108. Id. at $337-38,383 \mathrm{~A} .2 \mathrm{~d}$ at 1169 . The federal courts have also recognized the use of mandamus to challenge an order denying a jury trial. See Dairy Queen, Inc. v. Wood, 369 U.S. 469, 479-80 (1962). The reason for this grant of extraordinary relief rests in the seventh amendment right to a jury trial in civil matters. U.S. CoNST. amend. VII. The New Jersey Constitution contains a similar provision. N.J. CONST. art. I, para. 9. No cases have been found, however, in which the appellate division granted leave to appeal from an order denying a jury trial. Nevertheless, in Rybeck v. Rybeck, 150 N.J. Super: 151, 375 A.2d 269 (App. Div. 1977), the court recognized that appeals raising constitutional questions of public importance could trigger the exercise of its discretionary power of review. Id. at 155, $375 \mathrm{~A} .2 \mathrm{~d}$ at 271 . Consequently, the appeal of an order denying the right to a jury trial would undeniably raise such a question and thus could be granted review under the court's power. 
An additional factor in the preference of fixed rules for the federal courts may be the perceived explosion of litigation in the federal court system. This additional burden, created in part by new judicially-created rights of action, places a premium on systematic rules and predictable results. The costs of an individualized approach may not therefore be justified. Restrictive rules may provide some external discipline to prevent a continual and burdensome expansion of judiciallycreated rights in the area of interlocutory appeals.

The federal approach is thus governed by a statutorily-imposed set of restrictive rules and exceptions. Over time, however, an additional set of convoluted judicially-created exceptions has developed to cover situations in which the explicit statutory directives failed to serve "the interest of justice." Federal judicial discretion has been further expanded through the liberal use of extraordinary writs as a means of appellate review.

Perhaps, in light of structural and philosophical differences between the state and federal court systems, the New Jersey single-standard approach would not be as appropriate in the federal setting as a system of more predictable, restrictive rules. The choice is between a flexible, individually-oriented approach and a more consistent, uniform, and cost-efficient system. But the current federal system has in practice refused to accept and apply either of the alternatives. Its restrictive rules are riddled with exceptions originally created to avoid the occasional harsh result. The consequence is a system that, in spite of its aims, lacks simplicity, predictability, and, all too frequently, basic fairness. For those who believe that the time has come for reform of these neglected statutes, the New Jersey single standard of review may present a workable and equitable alternative to the current state of the federal interlocutory appeals. 
